\title{
Development of Preschool Children's Communication Skills Assessment Scale - Educator Form
}

\author{
Aydan Aydın ${ }^{1 *}$ \\ ${ }^{1}$ Marmara University, Atatürk Education Faculty, Special Education Department, 34722 Göztepe, Kadıköy, Istanbul, TURKEY \\ *Corresponding Author: aydanaydin@marmara.edu.tr \\ Citation: Aydın, A. (2019). Development of Preschool Children's Communication Skills Assessment Scale - Educator Form. Mediterranean \\ Journal of Social \& Behavioral Research, 3(3), 37-42. https://doi.org/10.30935/mjosbr/9592
}

Note: This article was presented in ICOINE 2014 : 3rd International Conference on Interdisciplinary Research in Education, 29-31 October 2014, Milano, Italy.

\begin{abstract}
The communication between the teacher and student is important in the educational process because it strengthens the interaction between them and helps students to better adapt to the educational environment. During the communication process, teachers' communication skills can be as effective as children's communication skills. This study aims to develop the teacher form of a scale that will be used to assess pre-school children's communication skills. Teachers assessing a total of 503 children took part in the study. In the process of developing the scale, principal components analysis was used in factor analysis. The common factor loads of the items of the scale and the loads they take from the factors they were in were calculated separately for each age group. It was found that the scales have sub-dimensions for all age groups, each item highly contributed to the common variance of the scales and the loads of factors in which each item was included were also high. The results of the Internal Consistency, Discrimination and Item Analysis for all modules showed that Cronbach's alpha internal consistency coefficients for all modules were high, the items included in the modules were highly related to the total scores of the module and the items in all the modules were distinctive for high and low groups.
\end{abstract}

Keywords: teacher form, communication scale, school scale

Received: 04 Aug. $2019 \bullet$ Revised: 30 Sep. $2019 \bullet$ Accepted: 07 Nov. 2019

\section{INTRODUCTION}

Communication is of the most effective ways through which individuals can express themselves and establish mutual interaction in their daily lives. During the school years, establishing relationships both with each other and with their teachers is also important for students for their adaptation to the school. Particularly, maintaining a mutual relationship between students and their teachers will pave the way for students to feel themselves more secure and provide with them the ability to effectively cope with possible problems. In some research studies, the importance of student-teacher communication is emphasized for the adaptation process of the children to the school (Pianta, Steinberg \& Rollins 1995) and for their development of problem solution skills (Ocak, 2010). It was indicated that a positive teacher-student relationship also has positive influences on children's adaptation, development of social skills and on the relationships with their peers (Birch \& Ladd, 1997; Hamre \& Pianta, 2001; Battistich, Schaps, \& Wilson, 2004; Hughes \& Kwok, 2007). As can be realized from the findings of these research studies, the communication between teachers and students is important in students' school years.
However, this communication process should be mutual rather than a one-way process.

In this mutual process, it is thought that in addition to the importance of having communication skills for teachers, it is similarly important for students to have communication skills complying with their developmental period. According to the results of some studies, children with emotional disorders or mental retardation have mostly negative relationships with their teachers (Murray \& Greenberg, 2001) and children with problematic behaviors have less intimate relationships with them (Birch \& Ladd, 1998; Murray \& Murray, 2004). There might be various reasons why preschool children have negative relationships with their teachers. Some of these reasons may be related to the psychological-emotional differences or disabilities of the teachers and students or to the communication skills of the children in this period. During the pre-school period, children are for the first time taught in a structured environment in which they perform their first experience of learning about life, and it is crucial for these children to able to express themselves because they adapt to the social life and participate in learning experiences by means of establishing 
communication skills. Besides, it is considered that these initial learning experiences of the children in a structured environment might have effects on their attitudes towards school and learning in general. On the contrary, in case of differences or inadequacies in the way children establish communication, their communication with their teachers and peers becomes more difficult. Moreover, if pre-school children cannot establish mutual and positive relationship with their teachers and peers or cannot express themselves, it is not very likely for them to get academic or adaptive benefits from the pre-school education. As defined by Dökmen (2005), communication is the exchange of information in its simple form and it is one of the most vital phenomena of life. It would be fair to state that children with lack of or delayed communication skills will be deprived of the information exchange process and will have difficulty in performing certain behaviors or skills appropriate to their age. When children cannot benefit sufficiently from the pre-school education, in which the basics of learning takes place, their learning experiences in their future life may be negatively influenced. Therefore, it is necessary to know what pre-school children's communication skills should be and in which aspects of these skills should be supported. Furthermore, it is thought that there is a need for an instrument through which students' different communication skills can be detected and the delay as well as the deficiencies of their communication skills can be assessed. For that reason, the need to develop an instrument that will enable teachers to be able to assess pre-school children's communication skills was focused in the present study. Thus, the aim of the current research study is to develop the teacher form of the scale intended to identify pre-school children's communication skills.

\section{METHOD}

This study is a scale development study. The stages followed to develop the "The Scale for the Identification of Pre-school Children's Communication Skills" and the participants of the study are explained below.

\section{Participants}

In this research study, the participating pre-schools providing education to children with normal development were determined via random sampling among the pre-schools of the National Ministry of Education in 11 different districts of the Istanbul province, and the participants of the study include parents of 427 children enrolled at 27 different pre-schools. On the other hand, parents of 76 autistic children chosen among six rehabilitation centers were selected via convenience sampling. Thus, the total number of participants was 503 parents. According to Ross (2005), convenience sampling is a type of sampling method based on the accessibility and suitability of the groups for the researcher making a decision about the sample in the whole population.

\section{Data Collection Instruments}

Ankara Developmental Screening Inventory (ADSI): This inventory assessing 0-6-year-old children's developmental levels and skills in line with the information obtained from their mothers includes 154 items. The questions in the inventory were formulated in such a way that they represent interrelated developmental areas (i.e., Language-Cognitive, Fine Motor, Gross Motor, Social Skills-SelfCare). The internal consistency of the inventory and the sub-tests ( $\mathrm{L}$ C, FM, GM, SS-SC) for the three age groups (0-12, 13-44 and 45-72 months) were determined by calculating their Cronbach Alpha Coefficients. The coefficients for Language-Cognitive are as follows: .93 for 0-12-monts, .97 for 13-44 months, .88 for 45-72 months; the coefficients for Fine Motor are: .93 for 0-12 months, .95 for 13-44 months, .84 for 45-72 months; the coefficients for Gross Motor are: .91 for 0-12 months, .80 for 13-44 months, .19 for 45-72 months; the coefficients for Social Skills-Self-Care are: .92 for $0-12$ months, .85 for 14-44 months, .37 for 45-72 months (Savaşır, Sezgin, Erol 1994).

The Development of the Scale for the Identification of Preschool Children's Communication Skills: The scale developed by the researcher is comprised of two parts, one of which is for parents while the other is for teachers. The items in both parts are exactly the same; however, the parents form was filled out by only parents while the teacher form was only responded by teachers. Initially containing 86 items, the scale was sent out to 17 referees in the field. Upon receiving the referees' views and evaluation, the number of referees making the comment that the item was "necessary" for each item was divided by half of the total number of referees making comments related to the item so that the rate of content validity (RCV) of the scale was calculated $(\mathrm{RCV}=3,58 / 67=0,795)$. The scale has 9 items for 0 - 1 -yearold children, 12 items for 1-2-year-old children, 13 items for 2-3-yearold children, 13 items for 3-4-year-old children, 8 items for 4-5-yearold children and 11 items for 5-6-year-old children. The instrument aiming to help teachers assess children's communication skills is a Likert type assessment tool. The five-point Likert type scale (i.e., "never", "rarely", "sometimes", “often", "always") also contains demographic variables about teachers and students.

\section{Data Collection and Analysis}

The developed scale was distributed to the identified organizations and the teachers were informed about how to fill it out. The forms were collected after the teachers fill them out. Among 1020 forms distributed in the process of data collection, 652 returned. 427 of the returned forms were taken into consideration for the study as the remaining forms were not filled out thoroughly by the participants. On the other hand, as a part of data collection, 250 scale forms were distributed to parents of autistic children and out of 250, 76 were taken into account for the study. In the analysis, the obtained data were subjected to KaiserMeyer-Olkin (KMO) to reveal the data's sampling adequacy and to Bartlett sphericity values to find its normality. Then, principal components analysis of factor analysis was applied. After calculating the common factor loads for the items separately for each age group and the loads they took from the factors they are in; the item total and the item remaining correlations were calculated for each item of the scale. In addition, Cronbach's Alpha internal consistency values for factors and comparative analysis were made to reveal scale discrimination. The relationship between all the items in all the modules and the total scores of the module were calculated by means of the Pearson product moment correlation coefficient analysis. Moreover, Pearson correlation analysis was applied to identify whether there was a significant relationship between the teacher form scores in all modules and the sub-dimension scores in ADSI, and the independent sample $t$ test was used to determine whether there was a significant difference in the arithmetic means of autistic and normal children. 
Table 1. Factor values and justified total variance table

\begin{tabular}{|c|c|c|c|c|c|c|c|c|c|}
\hline \multirow{2}{*}{ Module } & \multirow{2}{*}{ KMO } & \multirow{2}{*}{ Bart. $X^{2} / p$} & \multirow{2}{*}{ Fac. } & \multicolumn{3}{|c|}{ (Initial Eigen Values) } & \multicolumn{3}{|c|}{ Total Factor Loads } \\
\hline & & & & Tot. & Var.\% & Cum.\% & Tot. & Var.\% & Cum.\% \\
\hline \multirow{3}{*}{$0-1$} & \multirow{3}{*}{.918} & \multirow{3}{*}{$2422.14^{*}$} & 1 & 5.62 & 62.43 & 62.43 & 5.62 & 62.43 & 62.43 \\
\hline & & & 2 & 1.01 & 11.21 & 73.64 & 1.01 & 11.21 & 73.64 \\
\hline & & & 3 & .60 & 6.70 & 80.33 & & & \\
\hline \multirow{2}{*}{$1-2$} & \multirow{2}{*}{.944} & \multirow{2}{*}{$7349.26^{*}$} & 1 & 10.03 & 83.61 & 83.61 & 10.03 & 83.61 & 83.61 \\
\hline & & & 2 & .45 & 3.74 & 87.35 & & & \\
\hline \multirow{2}{*}{$2-3$} & \multirow{2}{*}{.943} & \multirow{2}{*}{$6299.33^{*}$} & 1 & 9.93 & 76.40 & 76.40 & 9.93 & 76.40 & 76.40 \\
\hline & & & 2 & .80 & 6.18 & 82.58 & & & \\
\hline \multirow{2}{*}{$3-4$} & \multirow{2}{*}{.955} & \multirow{2}{*}{$7278.64^{*}$} & 1 & 10.92 & 84.02 & 84.02 & 10.92 & 84.02 & 84.02 \\
\hline & & & 2 & .63 & 4.81 & 88.83 & & & \\
\hline \multirow{2}{*}{$4-5$} & \multirow{2}{*}{.942} & \multirow{2}{*}{$2465.05^{*}$} & 1 & 6.45 & 80.59 & 80.59 & 6.45 & 80.59 & 80.59 \\
\hline & & & 2 & .41 & 5.16 & 85.75 & & & \\
\hline \multirow{2}{*}{$5-6$} & \multirow{2}{*}{.940} & \multirow{2}{*}{$2744.87^{*}$} & 1 & 8.693 & 79.023 & 79.02 & 8.693 & 79.023 & 79.023 \\
\hline & & & 2 & .753 & 6.842 & 85.87 & & & \\
\hline
\end{tabular}

$* p<.001$

Table 2. Communalities of items for age groups and unrotated factor loads

\begin{tabular}{|c|c|c|c|c|c|c|c|c|c|c|c|c|}
\hline \multirow[b]{2}{*}{ Item } & \multicolumn{2}{|c|}{ Module 0-1 } & \multicolumn{2}{|c|}{ Module 1-2 } & \multicolumn{2}{|c|}{ Module 2-3 } & \multicolumn{2}{|c|}{ Module 3-4 } & \multicolumn{2}{|c|}{ Module 4-5 } & \multicolumn{2}{|c|}{ Module 5-6 } \\
\hline & $\begin{array}{c}\text { Common } \\
\text { Load }\end{array}$ & $\begin{array}{c}\text { Fac. } \\
\text { Load }\end{array}$ & $\begin{array}{c}\text { Common } \\
\text { Load }\end{array}$ & $\begin{array}{c}\text { Fac. } \\
\text { Load }\end{array}$ & $\begin{array}{c}\text { Common } \\
\text { Load }\end{array}$ & $\begin{array}{c}\text { Fac. } \\
\text { Load }\end{array}$ & $\begin{array}{c}\text { Common } \\
\text { Load }\end{array}$ & $\begin{array}{c}\text { Fac. } \\
\text { Load }\end{array}$ & $\begin{array}{c}\text { Common } \\
\text { Load }\end{array}$ & $\begin{array}{c}\text { Fac. } \\
\text { Load }\end{array}$ & $\begin{array}{c}\text { Common } \\
\text { Load }\end{array}$ & $\begin{array}{c}\text { Fac. } \\
\text { Load }\end{array}$ \\
\hline Item 1 & .628 & .676 & .868 & .932 & .671 & .819 & .797 & .893 & .786 & .886 & .751 & .867 \\
\hline Item 3 & .821 & .905 & .832 & .912 & .781 & .884 & .789 & .888 & .692 & .832 & .872 & .934 \\
\hline Item 4 & .838 & .504 & .802 & .896 & .779 & .883 & .890 & .944 & .848 & .921 & .843 & .918 \\
\hline Item 5 & .747 & .821 & .809 & .899 & .848 & .921 & .845 & .919 & .744 & .862 & .806 & .898 \\
\hline Item 7 & .592 & .704 & .889 & .943 & .828 & .910 & .751 & .866 & .846 & .920 & .867 & .931 \\
\hline Item 8 & .729 & .854 & .815 & .903 & .806 & .898 & .885 & .941 & .855 & .924 & .782 & .884 \\
\hline Item 9 & .738 & .856 & .871 & .933 & .833 & .912 & .895 & .946 & - & - & .696 & .834 \\
\hline Item 10 & - & - & .881 & .939 & .677 & .823 & .829 & .911 & - & - & .578 & .760 \\
\hline Item 11 & - & - & .751 & .867 & .799 & .894 & .814 & .902 & - & - & .748 & .865 \\
\hline Item 12 & - & - & .756 & .869 & .878 & .937 & .826 & .909 & - & - & - & - \\
\hline Item 13 & - & - & - & - & .773 & .879 & .806 & .898 & - & - & - & - \\
\hline
\end{tabular}

\section{FINDINGS}

Some statistical requirements are expected so that factor analysis could be applied in statistical research as the current one. The most frequently used values are Kaiser-Meyer-Olkin to reveal the sampling adequacy and Bartlett sphericity values to find its normality. Tavşancı (2010) states that when the KMO value is or above ,90, the sample size is considered to be excellent, and when the Bartlett value is significant, it means that the data comes from multivariate normal distribution; on the other hand, Sharma (1996) and Büyüköztürk (2008) indicate that for the data to be subjected to factor analysis, the KMO value should be above .60 and the Barlett sphericity test should be found significant. Therefore, the items included in the modules prepared for each age group were separately analyzed and the obtained data were presented in Table 1.

As can be realized in Table 1, in all the factor analysis, the KMO values were found to be higher than $.90\left(K M O_{\max }=.955 ; K M O_{\min }=\right.$ $.918)$ and the Barlett values were found significant $(p<.001)$. These values mean that the data is suitable for factor analysis. Following these results, the factor analysis was applied. Principal components analysis of the factor analysis was used and the eigen value was taken as 1 . Tavşancil (2010) states that the easiest method to determine the eigen value is to regard this value as 1 within the Kaiser normalization process. It was found that apart from the 0 -1-year-old group, the items had a single-factor structure for all the other age groups. Related to the items in the 0-1-year-old group, the eigen value above 1 had a twofactor structure but the differences between the first and the second factor were found to be very high (51\%). Çokluk, Şekercioğlu and Büyüköztürk (2010, p.221) point out that when the contribution of the factors to the total factor decreases, the factor number can be considered as 1 . As a result, the items in this group were also taken as one-factor for this study. In other words, all the items for each age group gathered in a one-factor factorial structure. Seçer (2013) emphasizes that it would be sufficient for the justified variance in one-factor designs to be $30 \%$ and above. The total loads factors justify (justified total variance percentage) were found to be at the lowest $62.43 \%$ (0-1 module) and at the highest $84.02 \%$ (3-4 module). Following these statistical procedures, the common factor loads of the factors for each age group and the loads they took from the factors they were in were calculated and presented in Table 2.

As illustrated in Table 2, the common factor loads of the items were calculated separately for each group and the loads they took from the factors they were in were found. According to Büyüköztürk (2008), it is important for an item not to take a load factor of less than $30 \%$ of the factor they are in. As a result of all the statistical procedures, it was found that the lowest factor load was found to be approximately $50 \%$. Similarly, the lowest communality values were found to be around $59 \%$. In other words, it was found that the scales had a sub-dimension for all age groups and each item highly contributed to the common variance 
Table 3. Results of internal consistency, discrimination and item analysis for all modules

\begin{tabular}{|c|c|c|c|c|c|c|c|c|}
\hline Module (Age) & M. Number & $\mathbf{x}$ & ss & C.Alpha & $\mathbf{r}_{\text {total (min) }}$ & $\mathbf{r}_{\text {total (Max) }}$ & $\mathbf{t}_{\min }$ & $t_{\max }$ \\
\hline $0-1$ & 9 & 41.45 & 6.49 & .91 & $.58^{*}$ & $.90^{*}$ & $-8.44^{*}$ & $-14.89^{*}$ \\
\hline $1-2$ & 12 & 53.54 & 13.05 & .98 & $.87^{*}$ & $.96^{*}$ & $-9.75^{*}$ & $-18.79^{*}$ \\
\hline $2-3$ & 13 & 54.23 & 15.64 & .97 & $.65^{*}$ & $.93^{*}$ & $-14.06^{*}$ & $-31.23^{*}$ \\
\hline $3-4$ & 13 & 53.23 & 17.21 & .98 & $.87^{*}$ & $.96^{*}$ & $-13.65^{*}$ & $.34 .72^{*}$ \\
\hline $4-5$ & 8 & 31.57 & 9.79 & .97 & $.56^{*}$ & $.64^{*}$ & $-8.21^{*}$ & $-11.63^{*}$ \\
\hline $5-6$ & 11 & 36.42 & 16.60 & .97 & $.45^{*}$ & $.94^{*}$ & $-6.29^{*}$ & $-43.44^{*}$ \\
\hline
\end{tabular}

$* p<.001$

Table 4. Results of internal consistency, distinctiveness and item analysis for all modules

\begin{tabular}{llll}
\hline Modules & N & r & \\
\hline Module 0-1 Parents-Teacher & 375 & .46 & .000 \\
Module 1-2 Parents-Teacher & 370 & .63 & .000 \\
Module 2-3 Parents-Teacher & 358 & .64 & .75 \\
Module 3-4 Parents-Teacher & 315 & 1.00 & .000 \\
Module 4-5 Parents-Teacher & 300 & .387 & .000 \\
Module 5-6 Parents-Teacher & 201 & .000 \\
\hline
\end{tabular}

Table 5. Results of relationship analysis between teacher form scores of all modules and ADSI sub-dimension scores

\begin{tabular}{|c|c|c|c|c|c|c|}
\hline Modules & & Linguistic & Fine motor & Gross motor & Social self-care & General Development \\
\hline \multirow{2}{*}{ Module 0-1 } & $\mathrm{r}$ & $.589^{*}$ & $.585^{*}$ & $.622^{*}$ & $.618^{*}$ & $.629^{*}$ \\
\hline & $\mathrm{N}$ & 377 & 377 & 377 & 377 & 377 \\
\hline \multirow{2}{*}{ Module 1-2 } & $\mathrm{r}$ & $.766^{*}$ & $.693^{*}$ & $.694^{*}$ & $.774^{*}$ & $.782^{*}$ \\
\hline & $\mathrm{N}$ & 377 & 377 & 377 & 377 & 377 \\
\hline \multirow{2}{*}{ Module 2-3 } & $\mathrm{r}$ & $.782^{*}$ & $.745^{*}$ & $.622^{*}$ & $.730^{*}$ & $.773^{*}$ \\
\hline & $\mathrm{N}$ & 368 & 368 & 368 & 368 & 368 \\
\hline \multirow{2}{*}{ Module 3-4 } & $\mathrm{r}$ & $.819^{*}$ & $.743^{*}$ & $.639^{*}$ & $.752^{*}$ & $.806^{*}$ \\
\hline & $\mathrm{N}$ & 330 & 330 & 330 & 330 & 330 \\
\hline \multirow{2}{*}{ Module 4-5 } & $\mathrm{r}$ & $.628^{*}$ & $.535^{*}$ & $.424^{*}$ & $.518^{*}$ & $.596^{*}$ \\
\hline & $\mathrm{N}$ & 298 & 298 & 298 & 298 & 298 \\
\hline \multirow{2}{*}{ Module 5-6 } & $\mathrm{r}$ & $.430^{*}$ & $.438^{*}$ & $.304^{*}$ & $.295^{*}$ & $.404^{*}$ \\
\hline & $\mathrm{N}$ & 220 & 220 & 220 & 220 & 220 \\
\hline
\end{tabular}

$* p<.001$

of the scales; in addition, the loads of the factors where each item was included were high. Following this finding, Cronbach's Alpha internal consistency values were found and comparative analysis for scale distinctiveness were calculated. After these procedures, total item and item remaining correlations were calculated for each scale. Tavşancıl (2010) maintains that as a test's reliability coefficient gets closer to 1.00, the scale becomes more reliable, and Büyüköztürk (2008) asserts that a calculated alpha value of .70 or above is sufficient for the reliability of the test scores in general. Another criterion of the effectiveness of the items and the total scale scores in the measurement of what is intended is their discrimination feature. According to Tavşancıl (2010), this statistical procedure is applied by considering the total scores obtained from the scale and by comparing the scores means of the high and low groups for each item after ranking the groups from highest score to the lowest. Büyüköztürk (2008) points out that following the ranking of the comparison operations, the differences in the arithmetic means of the high and low 27 groups in each item can be calculated by means of the independent sample $t$ test; also, finding the high groups in favor of the high group $(p<.05)$ can be regarded as an indication of the scale's internal consistency. On the other hand, the Pearson product moment correlation coefficient was used to reveal the relationship between the items in the modules and the total scores of the module. Özgüven (2007) indicates that items with a value of $r>.30$ are suitable items.

As can be realized in Table 3, the Cronbach's alpha internal consistency coefficient was found to be high for all the modules $\left(\alpha_{\min }=\right.$ $\left..91 ; \alpha_{\max }=.98\right)$. This means that all the modules had high levels of reliability. On the other hand, the items included in all the modules were highly related to the total score of the module $\left(r_{\min }=.45 ; r_{\max }=\right.$ $.96 ; p<.001)$. This finding shows that all the items in the modules contributed to the feature measured by the module. Finally, the items in all the modules were found to be distinctive for low and high groups $\left(t_{\min }=-6.29 ; t_{\max }=-43.44 ; p<.001\right)$. This means that all the items in the modules could significantly discriminate between high and low groups in terms of the features they measure. Then, the Pearson correlation and comparative analysis were carried out to determine the consistency between different observers (teacher-parents). The results are illustrated in Table 4.

As presented in Table 4, as a result of the Pearson correlation applied to determine the consistency between different observers (teacher-parents), it was found that the relationship values for all the scores were positively significant $\left(r_{\min }=.39 ; r_{\max }=1.00 ; p<.001\right)$. These values mean that the measurement values were consistent. Following this statistical procedure, Pearson correlation and comparative analysis were used to identify the relationship between the scores of different observers (teacher-parents) and ADSI sub-dimension scores. The results are given separately below for parents and teachers' scoring.

As presented in Table 5, as a result of the Pearson correlation analysis used to find whether there was a significant relationship between the teacher form scores of all modules and ADSI subdimension scores, it was realized that there are positively significant 
Table 6. Results of comparative analysis of the teacher form scores of all modules for autistic and normal children

\begin{tabular}{|c|c|c|c|c|c|c|c|c|}
\hline \multirow{2}{*}{ Module } & \multirow{2}{*}{ Groups } & \multirow{2}{*}{$N$} & \multirow{2}{*}{$\bar{x}$} & \multirow{2}{*}{$s s$} & \multirow{2}{*}{$S h_{\bar{x}}$} & \multicolumn{3}{|c|}{$t$ Test } \\
\hline & & & & & & $t$ & $S d$ & $p$ \\
\hline \multirow{2}{*}{ Module 0-1 } & Normal & 315 & 42.23 & 5.531 & .312 & \multirow{2}{*}{5.37} & \multirow{2}{*}{377} & \multirow{2}{*}{.000} \\
\hline & Autistic & 64 & 37.61 & 9.084 & 1.136 & & & \\
\hline \multirow{2}{*}{ Module 1-2 } & Normal & 315 & 55.63 & 10.657 & .600 & \multirow{2}{*}{7.40} & \multirow{2}{*}{377} & \multirow{2}{*}{.000} \\
\hline & Autistic & 64 & 43.25 & 18.050 & 2.256 & & & \\
\hline Module 2-3 & Normal & 311 & 56.90 & 13.585 & .770 & 8.19 & 368 & .000 \\
\hline \multirow{2}{*}{ Module 3-4 } & Normal & 288 & 56.42 & 14.598 & .860 & \multirow{2}{*}{9.81} & \multirow{2}{*}{330} & \multirow{2}{*}{.000} \\
\hline & Autistic & 44 & 32.34 & 18.528 & 2.793 & & & \\
\hline \multirow{2}{*}{ Module 4-5 } & Normal & 270 & 33.15 & 8.177 & .498 & \multirow{2}{*}{6.24} & \multirow{2}{*}{298} & \multirow{2}{*}{.000} \\
\hline & Autistic & 30 & 22.93 & 11.142 & 2.034 & & & \\
\hline \multirow{2}{*}{ Module 5-6 } & Normal & 188 & 38.54 & 16.039 & 1.170 & \multirow{2}{*}{4.68} & \multirow{2}{*}{220} & \multirow{2}{*}{.000} \\
\hline & Autistic & 34 & 24.71 & 14.821 & 2.542 & & & \\
\hline
\end{tabular}

relationships between all the scores $\left(r_{\min }=.30 ; r_{\max }=.82 ; p<.001\right)$. These values show that the teacher form scores of the scale are highly effective in terms of similar scale reliability. Following these statistical procedures, the independent sample $t$ test was applied to reveal whether the differences in the scores in all the modules for parents and teacher forms were significant for normal and autistic children's means. The results of this test are illustrated separately below for parents and teachers' sores.

As can be seen in Table 6, as a result of the independent sample t test applied to reveal whether there was a significant difference between arithmetic means of the teacher form scores for autistic and normal children, the difference between the means of all modules was found significant $\left(t_{\min }=4.68 ; p<.001\right)$. These differences were found to be in favor of the normal children. These results show that all the modules of the teacher form could be used to differentiate between normal and autistic groups.

\section{RESULTS AND DISCUSSIONS}

In this research study aiming to develop the teacher form of a scale that will be used to assess pre-school children's communication skills, the analysis of the data revealed that in all the factor analysis, the KMO values were above $.90\left(K M O_{\max }=.955 ; K M O_{\min }=.918\right)$ and the Bartlett values were found to be de significant $(p<.001)$. These values mean that the data could be subjected to factor analysis. Except for the 0-1-yearold group, the items had a single-factor structure. As for the items in the 0 -1-year-old group, it was found that the eigen value above 1 had a two-factor structure but the differences between the first and the second factor were found to be very high (51\%). The total loads justified by the factors (the justified total variance percentage) were calculated as $62.43 \%$ as the lowest (0-1 module) and the highest $84.02 \%$ (3-4 module). Following this analysis, the common factor loads of the items were separately calculated for each age group and the lowest factor load was found to be around $50 \%$ while the communality was approximately $59 \%$ at the lowest. Thus, it was revealed that the scales had sub-dimensions for all age groups and each item highly contributed to the common variance of the scale; moreover, the loads of the factors in which each item was included were found to be high. Following this statistical procedure, the item total and the item remaining correlations were applied for each scale item; the Cronbach's Alpha internal consistency values were used for the factors and comparative analysis were made for the scale discrimination. As a result of the analysis, it would be true to state that all the modules have higher level of reliability because the Cronbach's Alpha internal consistency coefficients $\left(\alpha_{\min }=.91 ; \alpha_{\max }=\right.$ .98) were found to be high for all the modules. On the other hand, the items all the modules were highly related to the total score of the module $\left(r_{\min }=.45 ; r_{\max }=.96 ; p<.001\right)$. This finding means that all the items in the modules contributed to the feature measured by the module. In addition, the items in all the modules were found to have discrimination value for high and low level groups $\left(t_{\min }=-6.29 ; t_{\max }=-\right.$ 43.44; $p$.001). These results show that all the items in the modules could significantly discriminate the high and the low ones in terms of the features they measure. Then, the Pearson correlation and relationship analysis were applied to reveal the consistently between the scores of different observers (teacher-student) and the relationship values were found to be positively significantly for all the scores $\left(r_{\min }=\right.$ .39; $\left.r_{\max }=1.00 ; p<.001\right)$. These values indicate that the measurement values were consistent. After this procedure, the Pearson correlation and relationship analysis were made to identify the relationship between the scores of different observers (teacher-student) and the ADSI sub-dimension scores. Positively significant relationships were found between the teacher form scores in all the modules and the ADSI sub-dimension scores $\left(r_{\min }=.30 ; r_{\max }=.82 ; p<.001\right)$. These values mean that the teacher form scores were effective in terms of similar scale validity. Finally, unrelated samples t-test was applied in order to reveal whether the differences in the arithmetic means of the scores taken from all the modules by normal and autistic children were significant and the difference in the arithmetic means in all the modules was found to be significant $\left(t_{\min }=4.68 ; p<.001\right)$. This difference was found to be in favor of the normal children. These findings show that all the modules of the teacher could be used to differentiate between normal and autistic groups.

As a result, it would be fair to conclude that the scale developed as a result of this study can be used by the teachers for the assessment of communication skills in the pre-school period. It is common knowledge that communication is one of the basic tools used for the continuation of human life (Cüceloğlu, 2005), and social life is based on communication. Therefore, there is a need for effective communication and conditions leading to it (Doğuş, 2011). As a structured environment, school enables children's development of communication skills by providing them with conditions suitable for their ages. According to Yavuzer (2001), a positive classroom environment is mostly dependent on the quality of the rapport teachers establish with their students. It can be suggested that teachers establishing good communication with their students can contribute a lot to their 
students in all aspects. Many studies have proved the importance of communication in the interaction process between students and teachers (Ergün and Özdaş, 1999; Ergin and Birol, 2000; Poyraz \& Dere, 2001; Hamre \& Pianta, 2001; Battistich, Schaps, \& Wilson, 2004; Hughes \& Kwok, 2007). Through the scale, which communication skills normal children have and do not have can be observed; on the other hand, in case of communication problems such as autism, the inadequacies of the pre-school children in terms of certain communication areas can be identified and necessary precautions can be taken. Thus, potential problems that may negatively affect communication in the school/classroom environment can be searched for through the scale. Besides, instead of feeling themselves incompetent, teachers who cannot establish proper communication with their students having communication-related difficulties should devise programs and methods addressing to their students' needs rather feeling themselves incompetent. For future studies, it can be recommended that the scale should be administered to a larger sample group and to children with various developmental features.

\section{REFERENCES}

Battistich, V., Schaps, E., \& Wilson, N. (2004). Effects of an elementary school intervention on students' "connectedness" to school and social adjustment during middle school. The Journal of Primary Prevention, 24(3), 243-262. https://doi.org/10.1023/B:JOPP $.0000018048 .38517 . c d$

Birch, S. H., \& Ladd, G. W. (1997). The teacher-child relationship and early school adjustment. Journal of School Psychology, 55(1), 61-79. https://doi.org/10.1016/S0022-4405(96)00029-5

Birch, S. H., \& Ladd, G. W. (1998). Children's interpersonal behaviors and the teacher-child relationship. Developmental Psychology, 34(5), 934-946. https://doi.org/10.1037/0012-1649.34.5.934

Büyüköztürk, Ş. (2008). Sosyal bilimler için veri analizi el kitabı. Ankara: Pegem Akademi.

Çokluk, Ö., Şekercioğlu, G., \& Büyüköztürk, Ş. (2010). Sosyal bilimler için çok değişkenli istatistik: SPSS ve LISREL uygulamalan. Ankara: Pegem Akademi.

Cüceloğlu, D. (2005). Yeniden insan insana. İstanbul: Remzi.

Doğuş, Y. (2011) Okul yöneticileri ve öğretmenlerin bakışı ile empatik iletişim. e-Journal of New World Sciences Academy, 6(1), 696-707.

Dökmen, Ü. (2005). Iletişim çatş̧malan ve empati. İstanbul: Sistem Yayıncilık.

Ergin, A., \& Birol, C. (2000). Eğitimde iletisim. Ankara, Anı Yayıncılık.
Ergün, M. \& Özdaş, A. (1999). Okul gözlemi ve uygulama çalışmalarının öğretmen adayları üzerindeki etkisi. AKÜ Sosyal Bilimler Dergisi, 3, 115-119.

Hamre, B. K., \& Pianta, R. C. (2001). Early teacher-child relationships and the trajectory of children's school outcomes through eighth grade. Child Development, 72, 625-638. https://doi.org/10.1111/ 1467-8624.00301

Hughes, J., \& Kwok, O. (2007). Influence of student-teacher and parent-teacher relationships on lower achieving readers' engagement and achievement in the primary grades. Journal of Educational Psychology, 99(1), 39-51. https://doi.org/10.1037/00220663.99.1.39

Murray, C., \& Greenberg, M. T. (2001). Relationships with teachers and bonds with school: Social and emotional adjustment correlates for children with and without disabilities. Psychology in the Schools, 38(1), 25-41. https://doi.org/10.1002/1520-6807(200101)38:1 $<25:$ :AID-PITS4>3.0.CO;2-C

Murray, C., \& Murray, K. M. (2004). Child level correlates of teacherstudent relationships: An examination of demographic characteristics, academic orientations, and behavioral orientations. Psychology in the Schools, 41(7), 751-762. https://doi.org/10.1002/pits.20015

Ocak, S., (2010). The effects of child-teacher relationships on interpersonal problem-solving skills of children. Infants $\&$ Young Children, 23(4), 312-322. https://doi.org/10.1097/ IYC.0b013e3181f27769

Özgüven, İ.E. (2007). Psikolojik testler. Ankara: Nobel Yayınları.

Pianta, R. C., Steinberg, M. S., \& Rollins, K. B. (2009). The first two years of school: Teacher-child relationships and deflections in children's classroom adjustment. Development and Psychopathology, 7(2), 295-312. https://doi.org/10.1017/S0954579400006519

Poyraz, H., \& Dere, H. (2001). Okulöncesi eğitiminin ilke ve yöntemleri. Ankara: Anı Yayıncılık.

Ross, K. N. (2005). Sample design for educational survey research. UNESCO.

Savaşır, I., Sezgin, N. ve Erol, N. (1994). Ankara gelişim tarama envanteri el kitabr. Ankara: Ankara Üniversitesi Tip Fakültesi.

Seçer, İ. (2013). SPSS ve LISREL ile pratik veri analizi. Ankara: Anı Yayıncilik.

Sharma, S. (1996). Applied multivariate techniques. New-York: John Wiley Inc.

Tavşancıl, E. (2010). Tutumlann ölçülmesi ve SPSS ile veri analizi. Ankara.

Yavuzer, H. (2001). Eğitim ve gelişim özellikleriyle okul çağı çocuğu. (7. Baskı). İstanbul: Remzi Kitabevi. 